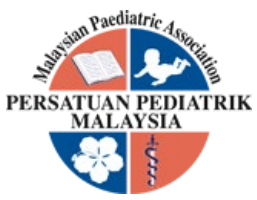

\title{
PREVALENCE OF ANAEMIA IN CHILDREN TREATED IN KEPALA BATAS, PENANG
}

\author{
Suria Emilia Suhana Othman Tan, Nurul Nadiah Ishak, Narazah Mohd Yusoff
}

\begin{abstract}
Objective: This study aimed to determine the prevalence of anaemia in children aged six months to fifteen years old treated in a single centre from 2008 to 2018. Methods: A retrospective study was conducted among 274 children age six months to fifteen years old, treated in Advanced Medical and Dental Institute (AMDI), Universiti Sains Malaysia (USM) from 2008 to 2018. The data was obtained from computerised hospital data (CARE2X), Laboratory Information System (LIS) or medical record. Parents of the eligible participants were called for any incomplete data and verbal consents were obtained. Descriptive analysis was conducted to determine the prevalence whereas the relationship between independent variables with types of anaemia were examined using simple logistic regression. Results: The prevalence of anaemia was $22.3 \%$. Among the anaemic children, the predominant morphology form was hypochromic microcytic anaemia (82\%) followed with normochromic normocytic anaemia (18\%). Iron deficiency anaemia (IDA) was found to be the commonest cause (24\%) of hypochromic microcytic anaemia, followed by IDA with concomitant thalassaemia (14\%) and thalassaemia alone (8\%). In simple logistic regression analysis, no significant association was found. Conclusions: The prevalence of anaemia was $22.3 \%$, which is considered as moderate public health problem according to WHO. Hypochromic microcytic anaemia was the predominant red cell morphology (82\%) and IDA was the commonest causes (24\%).
\end{abstract}

Keywords: Anaemia; Hypochromic microcytic; Iron deficiency anaemia; thalassaemia

\section{Introduction}

Anaemia has been acknowledged for many years as a public health issue and global prevalence remain unacceptably high. Anaemia occurs worldwide especially in developing countries, which have significant adverse health consequences and impact on social as well as economic development [1]. In the year 2011, almost $43 \%$ (270 million) of children are predicted to have anaemia globally which has been classified by the World Health Organization (WHO) as a severe public health issue [2]. WHO in 2016 has reported, the incidence of anaemia in children below five years age in Malaysia was $30.8 \%$ and need to be addressed urgently.
Received: 21 September 2020; Accepted revised manuscript: 20 October 2020

Published online: 18 November 2020
Anaemia refers to a reduced amount of circulating erythrocyte or haemoglobin concentration in the body [3]. Diagnosis of anaemia based on haemoglobin concentration is the most reliable indicator that defines anaemia in children as haemoglobin $(\mathrm{Hb})$ level less than $11 \mathrm{~g} / \mathrm{dL}$, less than $11.5 \mathrm{~g} / \mathrm{dL}$ and less than $12 \mathrm{~g} / \mathrm{dL}$ according to the respective age: six to fifty-nine months, five to eleven years old and twelve to fifteen years old [4].

\footnotetext{
Regenerative Medicine Cluster, Institut Perubatan dan Pergigian Termaju, Universiti Sains Malaysia, Bertam, 13200 Kepala Batas, Pulau Pinang

Corresponding author: Suria Emilia Suhana Othman Tan. Regenerative Medicine Cluster, Institut Perubatan dan Pergigian Termaju, Universiti Sains Malaysia, Bertam, 13200 Kepala Batas, Pulau Pinang, Malaysia Tel: 604-562 2553 Email: drsuriaemilia@usm.my
} 
Anaemia is further classified into hypochromic microcytic, normochromic normocytic and macrocytic by mean corpuscular volume (MCV) and mean corpuscular haemoglobin $(\mathrm{MCH})$ values. There are five main causes of microcytic anaemia, but only three of them are common in most part of the world, namely thalassaemia, iron deficiency anaemia (IDA) and anaemia of chronic disease (ACD) [5]. IDA and thalassaemia trait are the commonest cause of microcytic and hypochromic anaemia [6]. IDA is the world's third major cause of disability, the most common dietary disorder affecting both develop and developing countries and the $13^{\text {th }}$ major risk for life-adjusted global disability [7]. Studies have shown that there is a strong linked between iron deficiency with low growth rate and immunity, reduced cognitive development and high mortality among childhood anaemia [8]. Besides, IDA has been reported as high as $50 \%$ among East Asian children and as high as $60 \%$ among children under five years [9].

Thalassaemia is an inherited abnormalities of quantitative globin chains that occurring worldwide. Thalassaemia is also a public health problem affecting Malaysia's multi-ethnic population [10]. Ministry of Health Malaysia (MOH) estimated that between 150 and 350 babies are born with thalassaemia each year [11]. Recent study has found that approximately $6.8 \%$ of 32.6 million Malaysian population are thalassaemia carriers [12][13]. Thalassaemia carriers are often asymptomatic and usually detected during routine blood investigation or during family screening for thalassaemia. In contrast, children with beta thalassaemia major commonly presented with symptoms of anaemia such as pallor and failure thriving. These children would require life-long blood transfusion and iron chelation to maintain normal growth.

Studies on anaemia in Malaysia are abundant where these previous studies done in Malaysia were more focused specifically on IDA or thalassaemia and most of the studies were done in rural areas in West Malaysia in 2012 [14] and Kelantan in 2006 [15]. The findings of the previous study on anaemia and IDA among these children was high. However, there is no recent published study done to look at the prevalence of hypochromic microcytic anaemia and its commonest cause in Penang. Therefore, study on prevalence of anaemia in children treated in
Kepala Batas is important to provide a populationbased picture for the local authorities to look at the indicators of iron status and current trend of hypochromic microcytic anaemia; to enable specific measures be taken to improve the healthrelated issues among children in Penang. In this study, we aimed to determine the commonest type of anaemia in children age six months to fifteen years old treated in AMDI, USM and its commonest cause.

\section{Methods}

This was a retrospective study that was conducted in an out-patient clinic in AMDI, USM from October 2018 to June 2019. The study was approved by the Human Research and Ethics Committee (JEPeM), School of Medicine, Universiti Sains Malaysia (JEPeM Code: USM/JEPeM/18120758). Full blood count results of children age six months to fifteen years old treated in AMDI, USM from 2008 to 2018 were retrieved from the Laboratory Information System (LIS) and analysed. Blood results that fulfilled the criteria for anaemia were further analysed and classified into types of anaemia; hypochromic microcytic, normochromic normocytic and macrocytic. For results that falls into hypochromic microcytic categories, results of full blood picture, serum ferritin and haemoglobin analysis were also retrieved and reviewed to look for the causes of anaemia. Sociodemographic details of children with hypochromic microcytic and normochromic normocytic anaemia and the risk factors for developing anaemia were retrieved from the computerized hospital data (CARE2X) or medical record. Serum ferritin concentration of less than 15 nanogram $/ \mathrm{mL}$ was classify as iron deficiency anaemia. Parents of the eligible children were called for verbal consent and to enquire for incomplete data. Once consents were obtained, further information such as basic sociodemographic data of the child and parents, the well-being of the child during seeking treatment in AMDI, USM were collected. The conversations were recorded for consent purpose.

Data were analysed using IBM SPSS Statistics for Windows, Version 22 software. Univariable analysis (descriptive analysis) was conducted to determine or describe the prevalence of hypochromic microcytic anaemia, distribution of commonest type of anaemia and commonest causes of hypochromic microcytic anaemia in 
children age six months to fifteen years old treated in AMDI, USM. To summarise data, categorical variables were expressed as percentages. The relationship between the sociodemographic factors, nutritional intake and family or caregiver related factor with type of anaemia (hypochromic microcytic and normochromic normocytic anaemia) were analysed using Pearson's chisquare for relationship between two categorical variables and Mann-Whitney $U$ test, the nonparametric test that is equivalent to independent t-test. A p-value of less than 0.05 was taken as statistically significant.

Table 1. Sociodemographic characteristic of children age six months to fifteen years old with hypochromic microcytic anaemia $(n=50)$

\begin{tabular}{|c|c|c|}
\hline Variable & Category & $\begin{array}{l}\text { Hypochromic Microcytic } \\
\text { n (\%) }\end{array}$ \\
\hline \multirow[t]{4}{*}{ Age (years) } & $<1$ year & $30(60.0)$ \\
\hline & $2-5$ & $9(18.0)$ \\
\hline & $6-11$ & $7(14.0)$ \\
\hline & $12-15$ & $4(8.0)$ \\
\hline \multirow[t]{2}{*}{ Gender } & Male & $34(68.0)$ \\
\hline & Female & $16(32.0)$ \\
\hline \multirow[t]{2}{*}{ Race } & Malay & $49(98.0)$ \\
\hline & Chinese & $1(2.0)$ \\
\hline \multirow[t]{4}{*}{ Educational status } & $\begin{array}{l}\text { Not attending } \\
\text { school }\end{array}$ & $32(64.0)$ \\
\hline & Kindergarten & $13(26.0)$ \\
\hline & Primary school & $1(2.0)$ \\
\hline & Secondary school & $4(8.0)$ \\
\hline \multirow[t]{3}{*}{ Patient status } & USM dependent & $46(92.0)$ \\
\hline & Government & $2(4.0)$ \\
\hline & Public & $2(4.0)$ \\
\hline \multirow{3}{*}{$\begin{array}{l}\text { History of anti-helminth } \\
\text { medications }\end{array}$} & Yes & $14(31.1)$ \\
\hline & No & $2(4.4)$ \\
\hline & Not related & $29(64.4)$ \\
\hline \multirow[t]{2}{*}{ History of worm infestation } & Yes & $0(0)$ \\
\hline & No & $45(100.0)$ \\
\hline
\end{tabular}




\begin{tabular}{|c|c|c|}
\hline \multirow[t]{3}{*}{ Mother education } & Primary & $0(0)$ \\
\hline & Secondary & $5(11.1)$ \\
\hline & Tertiary & $40(88.9)$ \\
\hline \multirow[t]{3}{*}{ Father education } & Primary & $0(0)$ \\
\hline & Secondary & $7(15.6)$ \\
\hline & Tertiary & $38(84.4)$ \\
\hline \multirow[t]{2}{*}{ Consanguineous marriage } & Yes & $0(0.0)$ \\
\hline & No & $46(100.0)$ \\
\hline \multirow[t]{2}{*}{ Marital status } & Married & $44(97.8)$ \\
\hline & Divorce & $1(2.2)$ \\
\hline \multirow[t]{2}{*}{ Family history of thalassaemia } & Yes & $13(27.7)$ \\
\hline & No & $34(72.3)$ \\
\hline \multirow[t]{3}{*}{ Household income (RM) } & $<4360$ & $13(28.9)$ \\
\hline & $4360-9619$ & $27(60.0)$ \\
\hline & $>9619$ & $5(11.1)$ \\
\hline \multirow[t]{2}{*}{ Meat } & Yes & $24(53.3)$ \\
\hline & No & $21(46.7)$ \\
\hline \multirow[t]{2}{*}{ Vegetables } & Yes & $33(73.3)$ \\
\hline & No & $12(26.7)$ \\
\hline \multirow[t]{2}{*}{ Food made from grain } & Yes & $40(88.9)$ \\
\hline & No & $5(11.1)$ \\
\hline \multirow[t]{2}{*}{ Bean/nuts } & Yes & $26(57.8)$ \\
\hline & No & $19(42.2)$ \\
\hline \multirow[t]{2}{*}{ Tofu } & Yes & $23(51.1)$ \\
\hline & No & $22(48.9)$ \\
\hline \multirow[t]{2}{*}{ Baked potato } & Yes & $17(37.8)$ \\
\hline & No & $28(62.2)$ \\
\hline
\end{tabular}


Figure 1. showed the prevalence causes of hypochromic microcytic anaemia which include IDA, thalassaemia, IDA concomitant with thalassaemia and others or unknown causes. From fifty children with hypochromic microcytic anaemia, twelve (24\%) children had IDA. Seven (14\%) children were classified as having IDA concomitant with thalassaemia and four (8\%) children had thalassaemia alone. However, the prevalence of other or unknown causes contributes a higher percentage compared to the other group with the majority of $54 \%$ children classified into this group. In this study, among twelve patients with IDA, only nine children (75\%) age less than five years old have a serum ferritin concentration which ranges from $57.24 \mathrm{ng} / \mathrm{mL}$ with median (IQR) of $11.13(6.51,30.14)$.

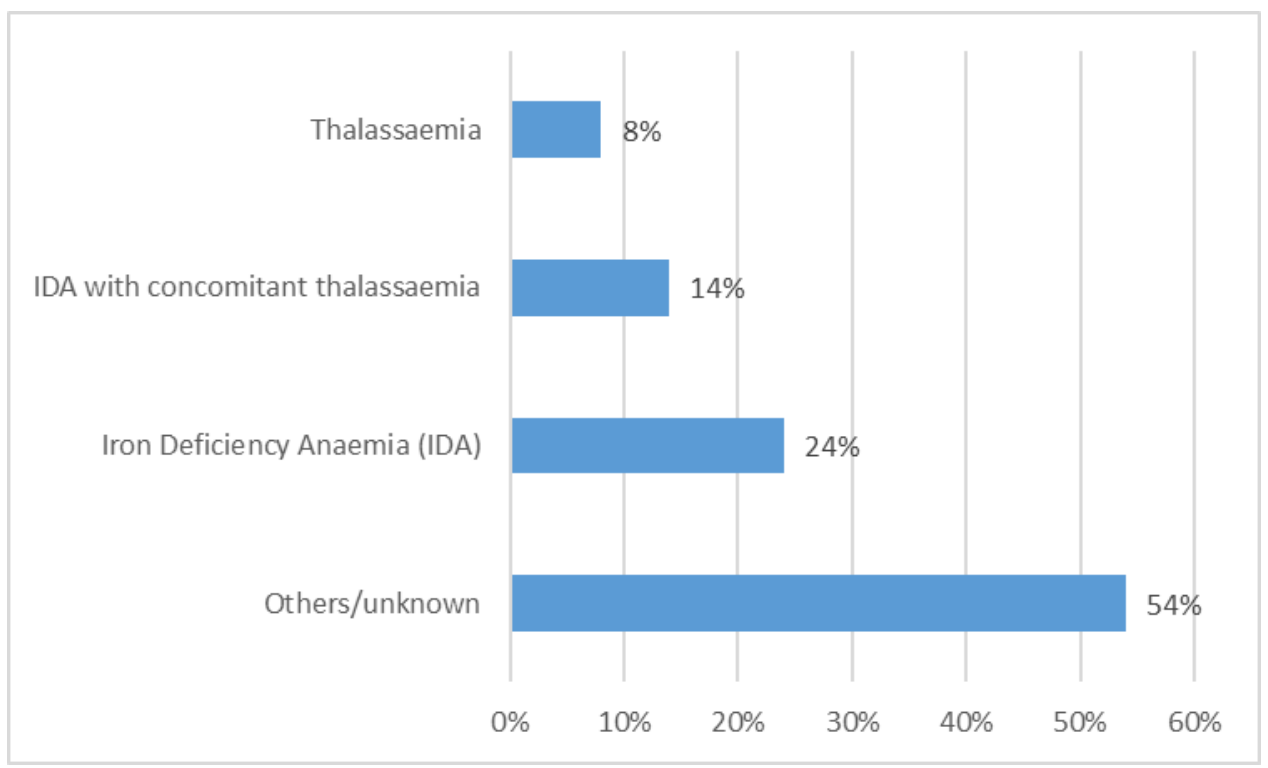

Figure 1. Causes of hypochromic microcytic anaemia in children age six months to fifteen years old treated in AMDI, USM

Table 2, 3 and 4 showed that there was no significant association between all categorical variables and types of anaemia (hypochromic microcytic and normochromic normocytic) with the respective $p$-value tested using Pearson's Chisquare test and Fisher's Exact test. Mann-Whitney test showed that there was no significant different between types of anaemia according to weight, height Body Mass Index (BMI), total number of children, household size, exclusive breastfeeding, age started solid food and age started formula milk.

Table 2. Correlation of sociodemographic factors with the type of anaemia in children age six months to fifteen years old treated in AMDI, USM $(n=61)$.

\begin{tabular}{|c|c|c|c|c|}
\hline \multirow[t]{2}{*}{ Variable } & Category & $\begin{array}{l}\text { Hypochromic } \\
\text { Microcytic }\end{array}$ & $\begin{array}{l}\text { Normochromic } \\
\text { Normocytic }\end{array}$ & p-value \\
\hline & & n (\%) & n (\%) & \\
\hline \multirow[t]{2}{*}{ Age (years) } & $<1$ year & $30(76.9)$ & $9(23.1)$ & $0.303^{a}$ \\
\hline & $2-5$ & $9(100.0)$ & $0(0.0)$ & \\
\hline
\end{tabular}




\begin{tabular}{|c|c|c|c|c|}
\hline & $6-11$ & $7(77.8)$ & $2(22.2)$ & \\
\hline & $12-15$ & $4(100.0)$ & $0(0.0)$ & \\
\hline \multirow[t]{2}{*}{ Gender } & Male & $34(87.2)$ & $5(12.8)$ & $0.182^{b}$ \\
\hline & Female & $16(72.7)$ & $6(27.3)$ & \\
\hline \multirow[t]{3}{*}{ Race } & Malay & $49(83.1)$ & $10(16.9)$ & $0.090^{\mathrm{a}}$ \\
\hline & Chinese & $1(100.0)$ & $0(0.0)$ & \\
\hline & Others & $0(0.0)$ & $1(100.0)$ & \\
\hline \multirow[t]{4}{*}{$\begin{array}{l}\text { Educational } \\
\text { status }\end{array}$} & $\begin{array}{l}\text { Not } \quad \text { attending } \\
\text { school }\end{array}$ & $32(86.5)$ & $5(13.5)$ & $0.308^{a}$ \\
\hline & Kindergarten & $13(92.9)$ & $1(7.1)$ & \\
\hline & Primary school & $1(50.0)$ & $1(50.0)$ & \\
\hline & Secondary school & $4(100.0$ & $0(0.0)$ & \\
\hline \multirow[t]{3}{*}{ Patient status } & USM dependent & $46(83.6)$ & $9(16.4)$ & $0.605^{\mathrm{a}}$ \\
\hline & Government & $2(66.7)$ & $1(33.3)$ & \\
\hline & Public & $2(100.0)$ & $0(0.0)$ & \\
\hline \multirow{3}{*}{$\begin{array}{l}\text { History of anti- } \\
\text { helminth } \\
\text { medication }\end{array}$} & Yes & $14(93.3)$ & $1(6.7)$ & $0.630^{\mathrm{a}}$ \\
\hline & No & $2(100.0)$ & $0(0.0)$ & \\
\hline & Not related & $29(85.3)$ & $5(14.7)$ & \\
\hline \multirow{2}{*}{$\begin{array}{l}\text { History of worm } \\
\text { infestation }\end{array}$} & Yes & $0(0.0)$ & $0(0.0)$ & - \\
\hline & No & $45(88.2)$ & $6(11.8)$ & \\
\hline $\begin{array}{l}\text { Weight (median, } \\
\text { IQR) }\end{array}$ & & $10.50(8.65,13.25)$ & $12.50(-)$ & $0.492^{*}$ \\
\hline $\begin{array}{l}\text { Height (median, } \\
\text { IQR) }\end{array}$ & & $85.00(76.25,99.25)$ & $96.30(-)$ & $0.483^{*}$ \\
\hline $\begin{array}{l}\text { BMI (median, } \\
\text { IQR) }\end{array}$ & & $14.35(13.35,15.49)$ & $13.48(-)$ & $0.161^{*}$ \\
\hline
\end{tabular}

a Pearson's Chi-square test

${ }^{\text {b}}$ Fisher's Exact test

* Mann-Whitney test

IQR: Interquartile Range 
Table 3. Correlation of caregiver related factor with the type of anaemia in children age six months to fifteen years old treated in AMDI, USM $(n=61)$

\begin{tabular}{|c|c|c|c|c|}
\hline \multirow[t]{2}{*}{ Variable } & \multirow[t]{2}{*}{ Category } & $\begin{array}{l}\text { Hypochromic } \\
\text { Microcytic }\end{array}$ & $\begin{array}{l}\text { Normochromic } \\
\text { normocytic }\end{array}$ & \multirow[t]{2}{*}{ p-value } \\
\hline & & n (\%) & n (\%) & \\
\hline \multirow[t]{3}{*}{ Mother education } & Primary & $0(0)$ & $0(0)$ & $0.520^{\mathrm{b}}$ \\
\hline & Secondary & $5(100.0)$ & $0(0.0)$ & \\
\hline & Tertiary & $40(87.0)$ & $6(13.0)$ & \\
\hline \multirow[t]{3}{*}{ Father education } & Primary & $0(0)$ & $0(0)$ & $0.298^{\mathrm{a}}$ \\
\hline & Secondary & $7(100.0)$ & $0(0.0)$ & \\
\hline & Tertiary & $38(86.4)$ & $6(13.6)$ & \\
\hline \multirow[t]{2}{*}{ Consanguineous marriage } & Yes & $0(0.0)$ & $0(0.0)$ & - \\
\hline & No & $46(88.5)$ & $6(11.5)$ & \\
\hline \multirow[t]{2}{*}{ Marital status } & Married & $44(88.0)$ & $6(12.0)$ & $1.000^{b}$ \\
\hline & Divorce & $1(100.0)$ & $0(0.0)$ & \\
\hline \multirow{2}{*}{$\begin{array}{l}\text { Family history of } \\
\text { thalassaemia }\end{array}$} & Yes & $13(100.0)$ & $0(0.0)$ & $0.317^{b}$ \\
\hline & No & $34(85.0)$ & $6(15.0)$ & \\
\hline \multirow[t]{3}{*}{ Household income (RM) } & $<4360$ & $13(92.9)$ & $1(7.1)$ & $2.283^{\mathrm{a}}$ \\
\hline & $4360-9619$ & $27(90.0)$ & $3(10.0)$ & \\
\hline & $>9619$ & $5(71.4)$ & $2(28.6)$ & \\
\hline $\begin{array}{l}\text { Total number of children } \\
\text { (median, IQR) }\end{array}$ & & $2.94(2.00,4.00)$ & $3.00(-)$ & $0.226^{*}$ \\
\hline Household size & & $5.00(4.00,6.00)$ & $5.00(-)$ & $0.237^{*}$ \\
\hline
\end{tabular}

a Pearson's Chi-square test

${ }^{b}$ Fisher's Exact test

* Mann-Whitney test

IQR: Interquartile Range 
Table 4. Correlation of nutritional intake with the type of anaemia in children age six months to fifteen years old treated in AMDI, USM ( $\mathrm{n}=61)$.

\begin{tabular}{|c|c|c|c|c|}
\hline \multirow[t]{2}{*}{ Variable } & \multirow[t]{2}{*}{ Category } & $\begin{array}{l}\text { Hypochromic } \\
\text { microcytic }\end{array}$ & $\begin{array}{l}\text { Normochromic } \\
\text { normocytic }\end{array}$ & \multirow[t]{2}{*}{$p$-value } \\
\hline & & n (\%) & n (\%) & \\
\hline \multirow[t]{2}{*}{ Meat } & Yes & 24 (88.9) & $3(11.1)$ & $1.000^{\mathrm{b}}$ \\
\hline & No & $21(87.5)$ & $3(12.5)$ & \\
\hline \multirow[t]{2}{*}{ Vegetables } & Yes & $33(89.2)$ & $4(10.8)$ & $0.661^{b}$ \\
\hline & No & $12(85.7)$ & $2(14.3)$ & \\
\hline \multirow[t]{2}{*}{ Food made from grain } & Yes & $40(87.0)$ & $6(13.0)$ & $1.000^{\mathrm{b}}$ \\
\hline & No & $5(100.0)$ & $0(0.0)$ & \\
\hline \multirow[t]{2}{*}{ Bean/nuts } & Yes & $26(92.9)$ & $2(7.1)$ & $0.390^{\mathrm{b}}$ \\
\hline & No & $19(82.6)$ & $4(17.4)$ & \\
\hline \multirow[t]{2}{*}{ Tofu } & Yes & $23(92.0)$ & $2(8.0)$ & $0.668^{b}$ \\
\hline & No & $22(84.6)$ & $4(15.4)$ & \\
\hline \multirow[t]{2}{*}{ Baked potato } & Yes & $17(77.3)$ & $5(22.7)$ & $0.073^{b}$ \\
\hline & No & $28(25.6)$ & $1(3.4)$ & \\
\hline $\begin{array}{l}\text { Exclusive breastfeeding } \\
\text { (median, IQR) }\end{array}$ & & $24.00(20.00)$ & $6.00(-)$ & $0.195^{*}$ \\
\hline $\begin{array}{l}\text { Age started formula } \\
\text { milk (median, IQR) }\end{array}$ & & $4.00(0.00,24.00)$ & $4.00(-)$ & $0.486^{*}$ \\
\hline $\begin{array}{l}\text { Age started solid food } \\
\text { (median, IQR) }\end{array}$ & & $6.00(6.00,6.00)$ & $0.00(0.00)$ & $0.395^{*}$ \\
\hline
\end{tabular}

a Pearson's Chi-square test

${ }^{b}$ Fisher's Exact test

* Mann-Whitney test

IQR: Interquartile Range

To determine sociodemographic factor, nutritional intake and family or caregiver related factors that were associated with the type of anaemia, simple logistic regression was performed. In the simple logistic regression analysis, there was no significant association was determined (table 5). Therefore, a multivariable logistic regression analysis was not being performed in this study. 


\section{Results}

A total of 274 blood results of children age six months to fifteen years old were included in this study. Sixty-one children (22.3\%) fulfilled the criteria for anaemia and remaining $77.7 \%$ were non-anaemic patient. Nearly all the anaemic children were observed to be more prevalent among Malays (22.2\%) compare to other races. From the sixty-one anaemic children, fifty (82\%) children had hypochromic microcytic anaemia and eleven (18\%) had normochromic normocytic anaemia.

The sociodemographic characteristics of fifty children age six months to fifteen years old with hypochromic microcytic anaemia are shown in Table 1. The magnitude of hypochromic microcytic anaemia among children aged less than one year, two to five years, six to eleven years and twelve to fifteen years were $60 \%, 18 \%, 14.0 \%$ and $80 \%$ respectively. It was obvious that the prevalence of hypochromic microcytic anaemia were highest among Malay (98\%) especially in male $(68 \%)$. More than half $(58 \%)$ of hypochromic microcytic anemia children had not received antihelminth medication and $28 \%$ had history of receiving anti-helminth medication before. However, there were no history of worm infestations among those children.

Majority of the mothers had tertiary education level $(88.9 \%)$ while $11.1 \%$ had education up to secondary level. $84.4 \%$ father had tertiary education level and another $15.6 \%$ had at least secondary education level. Majority of the caregivers not a consanguineous marriage (92\%) with $26 \%$ had a family history of thalassaemia and another $68 \%$ does not have a history of thalassaemia. More than half of the caregivers had a household income in range of RM 4360.00 to RM 9619.00 (54\%) followed with $26 \%$ for household income less than RM 4360.00 and $10 \%$ for household income more than RM 9619.00. Majority of hypochromic microcytic anaemia children consumed vegetables (73.3\%) and food made from grain (88.9\%). Almost more than half of the hypochromic microcytic anaemia children consumed bean (57.8\%) while $48.9 \%$ and $62.2 \%$ do not consume tofu and baked potato. 
Table 5. Associated factors for types of anaemia (hypochromic microcytic and normochromic normocytic) by simple logistic regression.

\begin{tabular}{|c|c|c|c|c|}
\hline Variables & $\begin{array}{l}\text { Regression } \\
\text { coefficient } \\
(\beta)\end{array}$ & $\begin{array}{c}\text { Crude Odds Ratio } \\
(95 \% \text { CI })\end{array}$ & $\begin{array}{c}\text { Wald } \\
\text { statistics }\end{array}$ & $P$-value \\
\hline \multicolumn{5}{|l|}{ Gender } \\
\hline Male & 0 & 1 & & \\
\hline Female & -0.94 & $0.392(0.10,1.48)$ & 1.91 & 0.167 \\
\hline Weight & 0.04 & $1.035(0.93,1.15)$ & 0.44 & 0.507 \\
\hline Height & -0.01 & $0.993(0.96,1.03)$ & 0.19 & 0.665 \\
\hline BMI & 0.52 & $1.688(0.70,4.07)$ & 1.36 & 0.244 \\
\hline \multicolumn{5}{|l|}{ Race } \\
\hline Malay & 0 & 1 & & \\
\hline Non-malay & -1.59 & $0.204(0.12,3.54)$ & 1.46 & 0.275 \\
\hline \multicolumn{5}{|l|}{ Educational status } \\
\hline Not attending school & 0 & 1 & & \\
\hline Kindergarten & 0.71 & $2.031(0.22,19.11)$ & 1.14 & 0.536 \\
\hline $\begin{array}{l}\text { Primary school and } \\
\text { Secondary school } \\
\text { Meat }\end{array}$ & -0.25 & $0.781(0.08,8.15)$ & 1.49 & 0.837 \\
\hline Yes & 0 & 1 & & \\
\hline No & -0.13 & $0.875(0.16,4.81)$ & 0.02 & 0.878 \\
\hline \multicolumn{5}{|l|}{ Vegetables } \\
\hline Yes & 0 & 1 & & \\
\hline No & -0.32 & $0.727(0.12,4.50)$ & 0.12 & 0.732 \\
\hline \multicolumn{5}{|l|}{ Bean/nuts } \\
\hline Yes & 0 & 1 & & \\
\hline No & -1.01 & $0.365(0.06,2.21)$ & 1.21 & 0.272 \\
\hline \multicolumn{5}{|l|}{ Tofu } \\
\hline Yes & 0 & 1 & & \\
\hline No & -0.74 & $0.478(0.08,2.88)$ & 0.65 & 0.421 \\
\hline \multicolumn{5}{|l|}{ Baked potato } \\
\hline Yes & 0 & 1 & & \\
\hline No & 2.11 & $8.235(0.89,76.59)$ & 3.43 & 0.064 \\
\hline $\begin{array}{l}\text { Exclusive } \\
\text { breastfeeding }\end{array}$ & 0.08 & $1.080(0.99,1.18)$ & 2.73 & 0.099 \\
\hline $\begin{array}{l}\text { Age started } \\
\text { formula milk }\end{array}$ & 0.10 & $1.10(0.96,1.27)$ & 1.82 & 0.177 \\
\hline $\begin{array}{l}\text { Total number of } \\
\text { children }\end{array}$ & -0.43 & $0.652(0.32,1.32)$ & 1.40 & 0.236 \\
\hline Household size & -0.44 & $0.646(0.31,1.33)$ & 1.40 & 0.237 \\
\hline $\begin{array}{l}\text { Household income } \\
\text { (RM) } \\
<4360\end{array}$ & 0 & 1 & & \\
\hline $4360-9619$ & -0.37 & $0.692(0.07,7.32)$ & 0.10 & 0.760 \\
\hline$>9619$ & -1.65 & $0.192(0.01,2.62)$ & 1.53 & 0.216 \\
\hline
\end{tabular}




\section{Discussion}

Estimation of incidence of anaemia is important in monitoring the children's health status in the country. Globally, the prevalence of anaemia in children was $42.6 \%$ which is higher compared to our present study (22.3\%). The prevalence of anaemia in our study has been considered as a moderate public health problem (20-39.9\%) by the WHO [4]. Prevalence of anaemia among children was higher in Northern Uganda (46.6\%) [13], North-Western Ethiopia (58.6\%) [17], Brazil (56.6\%) and Pakistan (62.3\%). WHO also reported that the magnitude of anaemia among children in South-East Asia was $53.8 \%$ and African Regions for $62.3 \%$ [18]. High prevalence of anaemia in African Regions compared to our study could be due to the reason that Africa as an underdeveloped country. Therefore, they have very low per capita real income and deep poverty. These countries might spend very little money on healthcare as well as education compared to developing countries like Malaysia.

Comparing our results with previous study done in Malaysia, our result is consistent with the study done among children age seven to twelve years old in remote and rural area of West Malaysia (26.2\%) [14]. Among aboriginal school children age seven to twelve years old in a remote area of Pos Betau, Pahang, Malaysia, 48.5\% children were anaemic [9]. In a study done on 544 Malaysian primary school-age children, anaemia was found to occur in $4 \%$ of the children [19].

In this study, the prevalence of anaemia is higher among male (24.5\%) which is in line to a study conducted in Uganda [1], Tanzania [20] and Equatorial Guinea [21]. Our study showed highest anaemic cases amongst children in age less than one years $(48.1 \%)$. This finding not in line to previous study done among children age six to fify-nine months in Uganda [1], which showed children aged twelve to twenty-three months contribute the highest percentage of anaemia (33.8\%). Our present study also showed anaemic cases among Malay children were higher compare to other race (22.2\%). However, our finding is not consistent with a study conducted among primary school children in Malaysia [19]. They found that the anaemic cases was highest among children of indigenous bumiputra (9.9\%) than other ethnicity. The study was conducted among primary school children from all six regions of Malaysia including Sabah and Sarawak while our study only focused on Kepala Batas district. So, the population in our study is more homogenous compared to their study.

\section{Prevalence Types of Anaemia}

Our study further revealed the predominant morphological form of anaemia in children was hypochromic microcytic anaemia, being observed in $82 \%$ of children followed with normochromic normocytic anaemia for $18 \%$. Prevalence of hypochromic microcytic was higher compared to the previous study conducted in Northen Uganda [16]. Their study shows the prevalence of hypochromic microcytic anaemia was $15.4 \%$ and slightly lower percentage for normochromic normocytic (10.1\%). Our results also showed a higher prevalence compared to the study conducted in Northwest Ethiopia [17] which showed prevalence of hypochromic microcytic of $62.2 \%$ and normochromic normocytic (36.9\%).

A study done among children under five years old in Tanzania [22] also showed that hypochromic microcytic anaemia was the commonest type of anaemia (37.5\%) occurring in children, followed by normochromic normocytic anaemia (33.3\%). Another study conducted on the children aged six months to thirty-six months in Bangladesh [23] reported a higher prevalence of anaemia children with microcytic anaemia (50.2\%), where else children with macrocytic anaemia of $5 \%$ and normocytic anaemia of $44.8 \%$. Although the percentage varies between studies, however, the finding is similar, where hypochromic microcytic as the most predominant occurring followed with normochromic normocytic anemia. Hypochromic microcytic anaemia occurs due to iron depletion indicative for iron deficiency anaemia (IDA) whereas the main factor contributes to normochromic normocytic anaemia are drug therapy or acute blood loss.

The prevalence of hypochromic microcytic anaemia among children aged less than one year, two to five years, six to eleven years and twelve to fifteen years were $60 \%, 18 \%, 14 \%$ and $80 \%$ respectively. A study conducted in Southwest Ethiopia [24] showed the prevalence of hypochromic microcytic anaemia was 53\% among school adolescents. In their study, among 408 adolescents, 134 (32.8\%) of them had at least one 
intestinal parasitic infections. High occurrence of hypochromic microcytic anaemia in adolescents might be due to increase requirement of iron for development and growth. In our study, almost all children did not have history of worm infestations.

\section{Causes of Hypochromic Microcytic Anaemia}

In this study, IDA contributed to the higher prevalence (24\%) followed with IDA concomitant with thalassaemia (14\%) and thalassaemia alone (8\%). Prevalence of IDA in our study was in line with previous studies that reported $21.2 \%$ to $22.6 \%$ had iron deficiency anaemia $[22,25]$. However, the incidence of IDA among anaemic children were reported to be higher in Pakistan (33.2\%) [26].

The magnitude of IDA in Malaysia varies in different part of the countries. Our result shows slightly higher compared to previous study conducted on rural children of West Malaysia [14]. Among a total of 550 children aged one to twelve years old, $16.9 \%$ were reported as IDA. However, IDA among anaemic children in Kelantan was higher (48.6\%) compared to our study [15]. Higher prevalence of IDA were also reported in other local studies, 36.5\% [27] and 34\% [9].

Most of the previous study conducted on thalassaemia in Malaysia were specifically on the quality of life, public perceptions and attitudes toward thalassaemia as well as the distribution of types of thalassaemia. A study on public perceptions and attitudes towards thalassaemia in Malaysia found that almost $4.5 \%$ to $6 \%$ of Malays and Chinese in Malaysia are carriers for thalassaemia [28]. A study on the distribution of alpha thalassaemia gene variants in diverse ethnic populations in Malaysia, alpha thalassaemia was reported on $52.2 \%$, especially among Malay, followed by Chinese, Indians, Sabahan, Sarawakians, Orang Asli and unspecific ethnicity [29]. In another previous study conducted among children aged fourteen to fifteen years old, 9.3\% were found to be carriers for thalassaemia, $2.9 \%$ for beta-thalassaemia, $2.6 \%$ for $\mathrm{HbE}$ beta thalassaemia and $1.3 \%$ for two-gene deletion of alpha-thalassaemia [12].

\section{Association between type of anaemia (hypochromic microcytic and normochromic normocytic) with socio-demographic factors, nutritional intake and family/caregiver related factor}

In this study, we have explored the associated aetiological factor of the types of anaemia (hypochromic microcytic anaemia and normochromic normocytic). However, there were no significant associated factors found. A study among children below five years of age attending St. Mary's Hospital Lacor, Gulu District, Northern Uganda [16] found that infestation with parasites, lack of complementary feeding and average of household income had statistically significant association factor for anaemia. Complementary feeding is one of the important nutritional supplementations for an infant starting from six month of age. Delay in starting complementary feeding has been found to be a strong causative factor for the development of IDA in young children. WHO also discuss in detail regarding the importance of complementary feeding. The term 'weaning' describes the crucial time for the nutritional requirement of an infant's diet through the gradual process of reducing breastfeeding or formula milk into semisolid food in addition to milk. Weaning is introduced with the goal of providing an adequate intake of energy for the child optimal growth. Weight of an infant's increases compared to their early first four to five months of life, failure to un-weaned from six months onwards and relying on the breast or formula milk alone unable to provide adequate energy for growth and development [30]. Infant in the age of six to twenty-four months were considered a vulnerable period due to increased risk of malnutrition. Therefore, complementary feeding should be given at six months of age in addition to breastfeeding with adequate frequency and amount. Variety of food also needed to cover the nutritional needs of growing. Breast milk alone without the need of other foods able to meet the requirement needs for the first six months. However, depletion of iron stores following growth leads to iron deficiency anaemia. This is due to the small quantity of iron and vitamin $D$ in the breast milk does not provide a sufficient supply, owing to high demand of body needed to replace the iron loss and rapid erythropoiesis.

Parasitic infection, not consuming meat and animal products, vomiting and diarrhea, as well as 
family or caregiver-related factor such as maternal education, was strongly associated with anaemia [17]. Choice of complementary foods introduced in an infant influences the iron status of the infant. However, it can be improved by diet that consist either haem iron or non-haem iron. Haem iron present in animal food sources whereas non-haem iron present in plant-based foods, iron-enriched and iron-fortified food [31]. Read meat, fish, poultry and seafood are the excellent source of haem iron and fortified foods such as breakfast cereals, formula milk, plant-based foods such as vegetables with the presence of the little amount of iron, nuts and bread as an indicator of nonhaem iron [32]. Anaemia can be prevented excellently by three interventions includes intake of variety of food with more bioavailable iron such as red meat, poultry and fish, fortified food such as infant cereal and breakfast cereal for full-term infants and children as well as iron supplementation for individual at risk [33]. The fraction of iron absorption in plant-based foods are less than $10 \%$, however with the consumption of meat and ascorbic acid, it will increase the absorption of the non-haem iron.

Maternal education is also interesting to be discussed as it may influence the foodconsumption behaviors. A study among Korean school aged children found that anaemia and iron deficiency less developed in children with more educated mothers [34]. Besides, result reported by a study in Tanzania also shown significant association of malaria parasite infestations and unemployment of caretakers with severe anaemia [22]. Higher maternal education can improve the mother's knowledge and awareness regarding health and nutrition due to access in knowledge and information, thus enabling them to increase and select good diets for their children. Besides, improve in education also is associated with the decision of dietary intake and care practices which then in line to the protection of children who at risk of poor health and nutrition especially in low and middle-income countries [35].

Previous data have showed a higher prevalence of anaemia in those with increase hookworm infestation [36]. However, there was no significant association has been shown with anaemia. This was in line with our study where there was no significant association between history of medication of worm and history of worm infection with types of anaemia. This might be due to the distribution of our study sample were below than one year of age. Deworming using albendazole (400 $\mathrm{mg}$ ) or mebendazole (500 mg) as the public health intervention recommended by $\mathrm{WHO}$ starting at the age of twenty-four months. Therefore, most of the children with anaemia in this study is still not indicated for anti-helminths.

\section{Conclusion}

In conclusion, the prevalence of anaemia in children six months to fifteen years old treated in AMDI, USM was $22.3 \%$ which is considered as moderate public health according to WHO. Among the anaemic children, the predominant morphology form was hypochromic microcytic anaemia followed with normochromic normocytic anaemia with prevalence of $82 \%$ and $18 \%$ respectively. In children with hypochromic microcytic anaemia, the highest prevalence is caused by IDA (24\%), followed with IDA with concomitant thalassaemia (14\%) and thalassaemia alone (8\%). In view of anaemia in children is still considered as an important health issues in Malaysia, routine screening of children with high risk of developing anaemia should be implemented and children affected be treated accordingly. 


\section{Acknowledgements}

This study was supported by a research grant from the University Sains Malaysia (USM Bridging Incentive Grant 2018, no akaun: 304.CIPPT.6316372).

\section{References}

[1] Kuziga, F., Adoke, Y. \& Wanyenze, R. K. (2017). Prevalence and factors associated with anaemia among children aged 6 to 59 months in Namutumba district, Uganda: a cross- sectional study. BMC Pediatrics, 17(1), 25. doi: 10.1186/s12887-017-0782-3

[2] Vieira, R., Livramento, A., Calheiros, M. S. C., Ferreira, C. M. X., Santos, T. R. D., Assuncao, M. L. \& Ferreira, H. D. S. (2017). Prevalence and temporal trend (2005-2015) of anaemia among children in Northeast Brazil. Public Health Nutrition 21(5), 1-9. doi: $10.1017 /$ S1368980017003238

[3] Vieth, J. T. \& Lane, D. R. (2014). Anemia. Emergency Medicine Clinics of North America, 32(3), 613-628. doi: https://doi.org/10.1016/j.emc.2014.04.007

[4] Word Health Organization (2011). Intermittent Iron Supplementation in Preschool and School-Age Children.

[5] Ford, J. (2013). Red blood cell morphology. Int J Lab Hematol, 35(3), 351-357. doi: 10.1111/ijlh.12082

[6] Januária F. Matosa, L. M. S. D., Karina B.G. Borgesb, Ricardo L.V. de Castroc, Wendel CouraVital d, Maria das G. Carvalhob (2016). A new index to discriminate between iron deficiency anemia and thalassaemia trait. rev bras hematol hemoter, 38(3), 214-219. doi: 10.1016/j.bjhh.2016.05.011

[7] Semedo, R. M. L., Santos, M. M. A. S., Baião, M. R., Luiz, R. R. \& da Veiga, G. V. (2014b). Prevalence of anaemia and associated factors among children below five years of age in Cape Verde, West Africa. Journal of health, population, and nutrition, 32(4), 646-657.

[8] Ngesa, O. \& Mwambi, H. (2014). Prevalence and risk factors of anaemia among children aged between 6 months and 14 years in Kenya. PLoS One, 9(11), e113756. doi: 10.1371/journal.pone.0113756
[9] Al-Mekhlafi, M. H., Surin, J., Atiya, A. S., Ariffin, W. A., Mahdy, A. K. M. \& Abdullah, H. C. (2008). Anaemia and iron deficiency anaemia among aboriginal school children in rural Peninsular Malaysia: an update on a continuing problem. Transactions of The Royal Society of Tropical Medicine and Hygiene, 102(10), 10461052. doi: 10.1016/j.trstmh.2008.05.012

[10] Mohd Ibrahim, H. et al. (2020) 'Observational study on the current status of thalassaemia in Malaysia: A report from the Malaysian Thalassaemia Registry', BMJ Open. doi: 10.1136/bmjopen-2020-037974.

[11] Ismail, A., Campbell, M. J., Ibrahim, H. M. \& Jones, G. L. (2006). Health Related Quality of Life in Malaysian children with thalassaemia. Health Qual Life Outcomes, 4, 39. doi: 10.1186/1477-7525-4-39

[12] Jameela, S., Sabirah, S. O., Babam, J., Phan, C. L., Visalachy, P., Chang, K. M., Salwana, M. A., Zuraidah, A., Subramanian, Y. \& Rahimah, A. (2011). Thalassaemia screening among students in a secondary school in Ampang, Malaysia. Med J Malaysia, 66(5), 522-524.

[13] Department of Statistics Malaysia Current population estimates, Malaysia, 2018-2019,2019. Available:https://www.dosm.gov.my/v1/index.ph $\mathrm{p} ? \mathrm{r}=$ column/pdfPrev\&id=aWJZRkJ4UEdKcUZpT2t VT090Snpydz09

[14] Ngui, R., Lim, Y. A., Chong Kin, L., Sek Chuen, C. \& Jaffar, S. (2012). Association between anaemia, iron deficiency anaemia, neglected parasitic infections and socioeconomic factors in rural children of West Malaysia. PLoS Negl Trop Dis, 6(3), e1550. doi: 10.1371/journal.pntd.0001550

[15] Siti-Noor, A. S., Wan-Maziah, W. M., Narazah, M. Y. \& Quah, B. S. (2006). Prevalence and risk factors for iron deficiency in Kelantanese preschool children. Singapore Med J, 47(11), 935-939.

[16] Ocan, A., Oyet, C., Webbo, F., Mwambi, B. \& Taremwa, I. M. (2018). Prevalence, morphological characterization, and associated factors of anemia among children below 5 years of age attending St. Mary's Hospital Lacor, Gulu District, Northern Uganda. Journal of blood medicine, 9, 195-201. doi: 10.2147/JBM.S184126 
[17] Enawgaw, B., Workineh, Y., Tadesse, S., Mekuria, E., Addisu, A. \& Genetu, M. (2019). Prevalence of Anemia and Associated Factors Among Hospitalized Children Attending the University of Gondar Hospital, Northwest Ethiopia. EJIFCC, 30(1), 35-47.

[18] World Health Organization (2015). The Global Prevalence of Anaemia in 2011. World Health Organization, 1-43.

[19] Nik Shanita, S., Siti Hanisa, A., Noor Afifah, A. R., Lee, S. T., Chong, K. H., George, P., Norazida, A. B., Budin, S. B., Khouw, I., Norimah, A. K. \& Poh, B. K. (2018). Prevalence of Anaemia and Iron Deficiency among Primary Schoolchildren in Malaysia. Int J Environ Res Public Health, 15(11). doi: 10.3390/ijerph15112332

[20] Kejo, D., Petrucka, P. M., Martin, H., Kimanya, M. E. \& Mosha, T. C. (2018). Prevalence and predictors of anemia among children under 5 years of age in Arusha District, Tanzania. Pediatric health, medicine and therapeutics, 9, 9-15. doi: 10.2147/PHMT.S148515

[21] Ncogo, P., Romay-Barja, M., Benito, A., Aparicio, P., Nseng, G., Berzosa, P., SantanaMorales, M. A., Riloha, M., Valladares, B. \& Herrador, Z. (2017). Prevalence of anemia and associated factors in children living in urban and rural settings from Bata District, Equatorial Guinea, 2013. PLoS One, 12(5), e0176613. doi: 10.1371/journal.pone.0176613

[22] Simbauranga, R. H., Kamugisha, E., Hokororo, A., Kidenya, B. R. \& Makani, J. (2015). Prevalence and factors associated with severe anaemia amongst under-five children hospitalized at Bugando Medical Centre, Mwanza, Tanzania. BMC Hematology, 15(1), 13. doi: 10.1186/s12878015-0033-5

[23] Hoque MM, Ahmed ASMNU \& $H, Q$. (2015). Prevalence and Risk Factors of Iron Deficiency Anaemia in Children admitted in a Tertiary Care Hospital of Bangladesh. Journal Nepal Paediatric Society, 35(1), 36-43. doi: 10.3126/jnps.v35i1.10495

[24] Gedefaw, L. et al. (2015) 'Anemia and iron deficiency among school adolescents: burden, severity, and determinant factors in southwest Ethiopia', Adolescent Health, Medicine and Therapeutics. doi: 10.2147/ahmt.s94865.
[25] Alaofè, H., Burney, J., Naylor, R. \& Taren, D. (2017). Prevalence of anaemia, deficiencies of iron and vitamin $A$ and their determinants in rural women and young children: a cross-sectional study in Kalalé district of northern Benin. Public Health Nutrition, 20(7), 1203-1213. doi: $10.1017 /$ S1368980016003608

[26] Habib, M. A., Black, K., Soofi, S. B., Hussain, I., Bhatti, Z., Bhutta, Z. A. \& Raynes-Greenow, C. (2016). Prevalence and Predictors of Iron Deficiency Anemia in Children under Five Years of Age in Pakistan, A Secondary Analysis of National Nutrition Survey Data 2011-2012. PLOSONE, 11(5), 1-13. doi: 10.1371/journal.pone.0155051

[27] Aini, U. N., Al-Mekhlafi, M. S., Azlin, M., Shaik, A., Sa'iah, A., Fatmah, M. S., Ismail, M. G., Firdaus, M. S., Aisah, M. Y., Rozlida, A. R. \& Norhayati, M. (2007). Serum iron status in Orang Asli children living in endemic areas of soiltransmitted helminths. Asia Pac J Clin Nutr, 16(4), 724-730.

[28] Wong, L. P., George, E. \& Tan, J. A. (2011). Public perceptions and attitudes toward thalassaemia: Influencing factors in a multi-racial population. BMC Public Health, 11, 193. doi: 10.1186/1471-2458-11-193

[29] Ahmad, R., Saleem, M., Aloysious, N. S., Yelumalai, P., Mohamed, N. \& Hassan, S. (2013). Distribution of alpha thalassaemia gene variants in diverse ethnic populations in malaysia: data from the institute for medical research. International journal of molecular sciences, 14(9), 18599-18614. doi: 10.3390/ijms140918599

[30] MacDonald, A. (2003). INFANTS | Weaning. In: Caballero, B. (ed.), Encyclopedia of Food Sciences and Nutrition (Second Edition). Oxford: Academic Press, pp 3293-3300.

[31] McDermid, J. M. \& Lönnerdal, B. (2012). Iron. Advances in Nutrition, 3(4), 532-533. doi: 10.3945/an.112.002261

[32] Aspuru, K., Villa, C., Bermejo, F., Herrero, P. \& López, S. G. (2011). Optimal management of iron deficiency anemia due to poor dietary intake. International journal of general medicine, 4, 741750. doi: 10.2147/IJGM.S17788

[33] Zlotkin, S. (2003). Clinical nutrition: 8. The role of nutrition in the prevention of iron deficiency anemia in infants, children and 
adolescents. CMAJ : Canadian Medical Association journal $=$ journal de l'Association medicale canadienne, 168(1), 59-63.

[34] Choi, H.-J., Lee, H.-J., Jang, H. B., Park, J. Y., Kang, J.-H., Park, K.-H. \& Song, J. (2011). Effects of maternal education on diet, anemia, and iron deficiency in Korean school-aged children. BMC public health, 11, 870-870. doi: 10.1186/14712458-11-870

[35] Harding, K. L., Aguayo, V. M., Masters, W. A. \& Webb, P. (2018). Education and micronutrient deficiencies: an ecological study exploring interactions between women's schooling and children's micronutrient status. BMC Public Health, 18(1), 470. doi: 10.1186/s12889-018-5312-1

[36] Molla, E. \& Mamo, H. (2018). Soiltransmitted helminth infections, anemia and undernutrition among schoolchildren in Yirgacheffee, South Ethiopia. BMC Research Notes, 11(1), 585. doi: 10.1186/s13104-018-3679-9 